\title{
Asupan vitamin B6, B9, B12 memiliki hubungan dengan risiko penyakit kardiovaskular pada lansia
}

\author{
Akhirul $^{1}$, Fransisca Chondro ${ }^{2}$
}

\begin{abstract}
ABSTRAK
\section{LATAR BELAKANG}

Indonesia akan memasuki periode lansia (aging), dimana 10\% penduduk akan berusia 60 tahun ke atas, di tahun 2020. Bertambahnya usia, penyakit tidak menular banyak muncul seperti hipertensi, stroke, dan diabetes melitus (DM). Menurut penelitian yang dilakukan oleh Gugun, asupan gizi atau mikronutrien antara lain asam folat, vitamin B6, dan B12 berpengaruh terhadap terjadinya resiko penyakit kardiovaskular dikarenakan asupan mikronutrien tersebut dapat menurunkan kadar homosistein yang berperan dalam pembentukan aterotrombosis.
\end{abstract}

\section{METODE}

Penelitian ini dilakukan menggunakan metode analitik observasional dengan pendekatan cross sectional. Pengambilan sampel dilakukan di Kelurahan Jelambar Baru RW 01 pada bulan September hingga Oktober 2018 dengan metode consecutive non random. Jumlah responden sebanyak 92 orang. Pengambilan data menggunakan data primer. Analisis data menggunakan uji Fisher dengan tingkat kemaknaan $(\mathrm{p})<0.05$.

\section{HASIL}

Terdapat hubungan yang bermakna secara statistik antara asupan vitamin B6, B9, dan B12 dengan risiko kardiovaskular pada lansia. Asupan vitamin B6 dengan kategori cukup mempunyai risiko rendah mengalami penyakit kardiovaskular dengan nilai kemaknaan $(\mathrm{p}=0.000)$, vitamin B9 asupan kategori kurang memiliki risiko sedang mengalami penyakit kardiovaskular $(\mathrm{p}=0.001)$, dan asupan vitamin B12 dengan asupan kategori kurang mempunyai risiko sedang mengalami risiko penyakit kardiovaskular $(\mathrm{p}=0.017)$.

\section{KESIMPULAN}

Dari hasil analisis data didapatkan hubungan antara asupan gizi vitamin B6, B9, dan B12 dengan risiko kardivaskular pada lansia, dimana asupan cukup vitamin B6, B9, dan B12 mengakibatkan risiko rendah untuk menderita penyakit kardiovaskular sedangkan asupan kurang dari vitamin B6, B9, dan B12 mengakibatkan risiko sedang dan tinggi untuk menderita penyakit kardiovaskular.

Kata kunci : vitamin B, homosistein, risiko penyakit kardiovaskular
${ }^{1}$ Program Studi Sarjana

Kedokteran, Fakultas Kedokteran Universitas Trisakti, Indonesia

2 Departemen Ilmu Faal, Fakultas Kedokteran Universitas Trisakti, Indonesia

\section{Korespondensi:}

Fransisca Chondro

Departemen Ilmu Faal, Fakultas

Kedokteran Universitas Trisakti,

Indonesia, Jalan Kyai Tapa No. 260, Grogol, Jakarta Barat

Email: fransisca_chondro@trisakti. ac.id

J Biomedika Kesehat 2019;2(3):111-116 DOI: 10.18051/JBiomedKes.2019. v2.111-116

pISSN: 2621-539X / eISSN: 2621-5470

Artikel akses terbuka (open access) ini didistribusikan di bawah lisensi Creative Commons Attribution 4.0 International (CC-BY 4.0) 


\section{ABSTRACT}

\section{Nutritional intake of vitamin b6, b9, b12, and cardiovascular risk in the elderly}

\section{BACKGROUND}

Indonesia will enter the period of aging where $10 \%$ of the population will be aged 60 years and above, in 2020 . Increasing age, many non-communicable diseases arise such as hypertension, stroke, and Diabetes Mellitus (DM). Based on study by Gugun, it is known that nutritional intake or micronutrients include folic acid, vitamin B6, and $\mathrm{B} 12$ affect the risk of cardiovascular disease. It is because the intake of micronutrients can reduce homocysteine levels which play a role in the formation of atherothrombosis.

\section{METHODS}

This study was conducted using an observational analytic method with a cross sectional approach. Samples were taken in Kelurahan Jelambar Baru RW 01 on September until October 2018, by using consecutive non random sampling method for each respondent who fulfilled the inclusion criteria. The number of respondents' data was 92 people. Data analysis was done by Fisher exact test with $\mathrm{p}$ value $<0.05$.

\section{RESULT}

There was a correlation between vitamin B6, B9, and B12 intake with cardivascular risk in the elderly. Vitamin B6 intake with sufficient category had a low risk of cardiovascular disease with a significance value $(p=0.000)$, vitamin B9 intake in the category of less risk of experiencing disease cardiovascular $(\mathrm{p}=0.001)$, and intake of vitamin B12 with intake of a category that is less at risk of experiencing the risk of cardiovascular disease $(p=0.017)$.

\section{CONCLUSION}

From the results of the data analysis there is a correlation between nutritional intake of vitamins B6, B9, and $\mathrm{B} 12$ with cardivascular risk in the elderly, where adequate intake of vitamins B6, B9, and B12 has a low risk of cardiovascular disease while lack intake of vitamin B6, B9, and B12 has a moderate and high risk of experiencing cardiovascular disease.

Keywords : vitamin B, homocysteine, cardiovascular disease risk

\section{PENDAHULUAN}

Lanjut usia adalah seseorang yang mencapai usia 60 tahun ke atas. Indonesia akan memasuki periode lansia (aging), dimana 10\% penduduk akan berusia 60 tahun ke atas, di tahun 2020 . Dengan bertambahnya usia, fungsi fisiologis pada manusia pun akan mengalami penurunan akibat proses penuaan tersebut sehingga penyakit tidak menular banyak muncul. Selain itu, masalah degeneratif menurunkan daya tahan tubuh sehingga lanjut usia menjadi lebih rentan terkena infeksi penyakit menular. Hasil Riskesdas 2013 menyatakan bahwa penyakit terbanyak pada lanjut usia adalah Penyakit Tidak Menular (PTM) antara lain hipertensi, artritis, stroke, Penyakit Paru Obstruktif Kronik (PPOK) dan Diabetes Mellitus (DM) ${ }^{(1,2)}$

Adanya gangguan fungsi organ yang rentan terjadi pada lansia dapat disebabkan oleh beberapa faktor, antara lain faktor genetik, penyakit tertentu, ataupun dipengaruhi oleh asupan gizi pada lansia. Asupan gizi yang dimaksud dalam hal ini yaitu mikronutrien antara lain asam folat, vitamin B6, dan B12 yang berpengaruh terhadap terjadinya resiko penyakit kardiovaskular, dimana asupan mikronutrien tersebut dapat menurunkan kadar homosistein yang berperan dalam pembentukan aterotrombosis yang mengakibatkan peningkatan terjadinya risiko penyakit kardiovaskular. ${ }^{(3)}$ Vitamin B6 terdiri atas derivat piridin yang berhubungan erat yaitu piridoksin, piridoksal serta piridoksamin dan derivat fosfatnya yang bersesuaian. Bentuk aktif dari vitamin $\mathrm{B}_{6}$ adalah piridoksal fosfat. ${ }^{(4)}$ Piridoksal fosfat juga terlibat dalam proses glikogenolisis yaitu pada enzim yang memperantarai proses pemecahan glikogen..$^{(4,5)}$ Bentuk aktif asam folat (pteroyl glutamate) adalah tetrahidrofolat, tetrahidrofolat ini merupakan pembawa unit-unit satu karbon yang aktif dalam berbagai reaksi oksidasi yaitu metil, metilen, metenil, formil, dan formimino. Tetrahidrofolat, peran metionin sintase menjadi vital, dan merupakan penghubung antara fungsi folat dan vitamin B12. Defisiensi fungsional folat yang menyebabkan kegagalan remetilasi homosistein menjadi metionin. Asam folat diketahui dapat memicu pertumbuhan sel serta proliferasi matriks dan sel otot polos endotel yang dapat meningkatkan risiko in stent restenosis. ${ }^{(4-6)}$ Vitamin B12 disintesis secara eksklusif oleh mikroorganisme walaupun demikian, vitamin B12 hanya ditemukan dalam makanan yang berasal dari hewan dan tidak ada tumbuhan yang merupakan sumber vitamin ini. Hal ini berarti vegetarian ketat berisiko mengalami 
defisiensi vitamin B12. Metionin yang diperlukan untuk sintesis SAM (S-Adenosyl methionine) dapat diperoleh dari makanan atau dibentuk dari homosistein yang menerima sebuah gugus metil dari vitamin B12, dengan demikian gugus metil pada metionin dibentuk kembali. ${ }^{(4,5,7)}$

Homosistein adalah asam amino sulfhidril, yang merupakan senyawa antara yang terbentuk dalam metabolisme asam amino esensial metionin dan banyak berasal dari protein hewani. Peningkatan hemosistein disebabkan oleh mutasi genetik, defisiensi vitamin, penyakit ginjal dan penyakit lainnya, obat-obatan dan peningkatan usia. Peningkatan homosistein menyebabkan peningkatan pembentukan aterotrombosis. Homosistein menyebabkan stres oksidatif, kerusakan endotel (disfungsi endotel) dan memacu thrombosis. Aterosklerosis merupakan suatu respons radang kronik dinding arteri yang dicetuskan oleh adanya cedera endotel (disfungsi endotel). ${ }^{(8)}$ Penyebab dari cedera atau disfungsi endotel adalah peningkatan kadar LDL dan radikal bebas yang disebabkan oleh merokok sigaret, hipertensi, diabetes melitus, faktor genetik, peningkatan konsentrasi plasma homosistein, infeksi mikroorganisme seperti virus herpes atau chlamydia pneumoniae, dan kombinasi dari faktor-faktor ini. ${ }^{(9)}$

Penelitian oleh Chambers et al menyatakan bahwa kadar homosistein di dalam plasma merupakan salah satu faktor penyebab meningkatkan risiko penyakit kardiovaskular. Peningkatan kadar homosistein serus tersebut mungkin berkaitan dengan rendahnya kadar asam folat dan vitamin B12 di dalam darah, sehingga dapat disimpulkan bahwa peningkatan asupan vitamin B tersebut dapat menurunkan risiko terjadinya penyakit kardiovaskular. ${ }^{(10)}$ Studi yang dilakukan oleh Debreceni et al menyatakan bahwa beberapa vitamin yakni vitamin B (asam folat, B6 dan B12), vitamin $C$, vitamin $D$, dan vitamin $\mathrm{E}$ memiliki efek yang menguntungkan untuk mempertahankan kesehatan kardiovaskular dan mencegah terjadinya penyakit kardiovaskular. ${ }^{(11)}$ Namun, studi yang dilakukan oleh Zhang et al mendapatkan hasil bahwa suplementasi vitamin B tidak memiliki pengaruh yang bermakna pada terjadinya stroke tromboemboli yang tidak fatal, jumlah mortalitas, kejadian infark miokard dan stroke. $^{(12)}$ Dengan mengacu pada data Riskesdas
2013 mengenai peningkatan populasi lansia pada beberapa dekade kedepan dengan risiko terjadinya penyakit kardiovaskular akibat bertambahnya usia serta adanya perbedaan hasil dari penelitian terdahulu, maka peneliti tertarik untuk melakukan penelitian mengenai hubungan vitamin $\mathrm{B}$ dengan risiko penyakit kardiovaskular pada lansia.

\section{METODE}

Penelitian ini dilakukan menggunakan metode analitik observasional dengan pendekatan cross sectional untuk mengetahui hubungan asupan gizi dengan risiko penyakit kardiovaskular pada lansia. Penelitian ini dilakukan di Kelurahan Jelambar Baru RW 01 Jakarta Barat pada bulan September hingga Oktober 2018. Populasi dalam penelitian ini yaitu seluruh lansia berusia 60 tahun ke atas di Kelurahan Jelambar Baru RW 01 Jakarta Barat. Kriteria inklusi pada penelitian ini adalah individu dengan usia 60 tahun ke atas dan masih dapat berkomunikasi dengan baik, sedangkan kriteria eksklusi pada penelitian ini adalah lansia dengan riwayat penyakit ginjal. Besar sampel pada penelitian ini sebanyak 92 responden dan menggunakan metode consecutive non random sampling. Dalam penelitian ini data yang digunakan adalah data primer yang didapatkan dengan menggunakan FFQ dan $\mathrm{WHO} /$ ISH prediction charts. FFQ (Food Frequency Questionnaire) digunakan untuk menilai asupan mikronutrien (vitamin B6, B12, asam folat) dan WHO/ISH Risk prediction charts digunakan untuk mengukur tingkat risiko penyakit kardiovaskular.

\section{HASIL}

Distribusi jenis kelamin, asupan vitamin, risiko penyakit kardiovaskular, merokok dan diabetes mellitus disajikan pada Tabel 1 .

Hasil data menunjukkan bahwa mayoritas lansia pada penelitian ini adalah berjenis kelamin perempuan sebesar 54 (58.7\%). Ditinjau dari angka kecukupan asupan (vitamin B6, B9, dan B12) yang dianjurkan oleh Menteri kesehatan perorang perhari khususnya pada usia 60 tahun ke atas didapatkan responden dengan asupan vitamin B6 sebanyak 76 orang (82.6\%) dalam kategori cukup. Berikutnya sebesar (51.1\%) 47 orang menunjukan kurangnya asupan vitamin B9, sebesar $(52.2 \%)$ dan 48 orang asupan vitamin B12 dalam kategori cukup. Sebanyak 55 orang 
(59.8\%) lansia memiliki tingkat risiko rendah mengalami penyakit kardiovaskular. Sebanyak 77 orang $(83.7 \%)$ lansia tidak mempunyai kebiasaan merokok yang berpengaruh pada tingkat risiko mengalami penyakit kardiovaskular dan berikutnya sebanyak 83 orang $(90.2 \%)$ lansia tidak mempunyai riwayat penyakit diabetes melitus yang berperan dalam menentukan tingkat risiko mengalami penyakit kardiovaskular.

Tabel 1. Distribusi jenis kelamin, asupan vitamin, risiko penyakit kardiovaskular, merokok dan diabetes melitus

\begin{tabular}{lc}
\hline \multicolumn{1}{c}{ Variabel } & n (\%) \\
\hline Jenis Kelamin & $38(41.3)$ \\
Laki-laki & $54(58.7)$ \\
Perempuan & $16(17.4)$ \\
Vitamin B6 & $76(82.6)$ \\
Kurang & \\
Cukup & \\
Vitamin B9 & $47(51.1)$ \\
Kurang & $45(48.9)$ \\
Cukup & \\
Vitamin B12 & $48(52.2)$ \\
Kurang & $44(47.8)$ \\
Cukup & \\
Risiko penyakit kardiovaskular & $55(59.8)$ \\
Rendah & $33(35.9)$ \\
Sedang & $4(4.3)$ \\
Tinggi & \\
Merokok & $77(83.7)$ \\
Tidak & $15(16.3)$ \\
Ya & \\
Diabetes melitus & $83(90.2)$ \\
Tidak & $9(9.8)$ \\
Ya &
\end{tabular}

Keterangan: $n=$ jumlah sampel

Hubungan asupan gizi (vitamin B6, B9, dan B12) dengan risiko penyakit kardiovaskular disajikan pada Tabel 2.

Berdasarkan Tabel 2, didapatkan bahwa asupan vitamin B6 dengan kategori cukup sebanyak 53 responden (26.9\%) memiliki risiko rendah mengalami penyakit kardiovaskular dan asupan dengan ketegori kurang sebanyak 11 (68.8\%) dari total 92 responden memiliki risiko sedang mengalami penyakit kardiovaskular, hubungan asupan vitamin B6 dengan risiko penyakit kardiovaskular memiliki nilai $\mathrm{p}=0.000$ yang artinya nilai tersebut bermakna, selanjutnya asupan vitamin B9 dengan kategori cukup sebanyak 35 responden (26.3\%) risiko rendah untuk mengalami penyakit kardiovaskular sedangkan responden dengan asupan kategori kurang sebanyak 23 orang (16.9\%) menunjukan risiko sedang mengalami penyakit kardiovaskular dari total 92 responden sehingga hubungan asupan vitamin B9 dengan risiko penyakit kardiovaskular memiliki nilai $\mathrm{p}=0.001$ menunjukkan adanya hubungan antara kedua variabel tersebut, dan analisis uji yang terakhir menunjukkan sebanyak 33 responden $(26.3 \%)$ asupan vitamin B12 dengan kategori cukup mengalami risiko rendah penyakit kardiovaskular dan asupan dengan kurang mengalami risiko sedang penyakit kardiovaskular sebanyak 23 responden (17.2\%) dari total 92 responden dengan nilai $\mathrm{p}=0.017$ sehingga bisa dikatakan terdapat hubungan antara variabel tersebut.

\section{PEMBAHASAN}

Pada penelitian ini di dapatkan asupan jenis vitamin yang paling banyak yaitu vitamin B6 76 orang $(82.6 \%)$ hal ini dikarenakan jenis makanan yang mudah ditemukan dalam kehidupan seharihari seperti nasi, tahu, tempe, bayam, ikan asin, pisang dan papaya. Asupan vitamin yang cukup khususnya vitamin B6, B9, dan B12 akan menurunkan risiko kardiovaskular, hal ini terjadi karena dalam metabolisme homosistein ketiga vitamin tersebut mempunyai peran masing-masing dalam 2 jalur metabolisme homosistein yaitu jalur reaksi transmetilasi dan jalur transsulfurasi atau jalur remetilasi serta ketiga vitamin tersebut juga berperan dalam pengaktifkan enzim untuk memetabolisme homosistein. ${ }^{(13,14)}$ Teori tersebut juga didukung hasil penelitian yang menyatakan bahwa peningkatan konsentrasi homosistein menyebabkan peningkatan oklusi pembuluh darah dan juga peningkatan konsentrasi homosistein di darah lebih dari $15 \mathrm{mmol} / \mathrm{L}$ biasa ditemukan 20-30\% pada pasien aterosklerosis. ${ }^{(15)}$ Pada usia lanjut risiko mengalami penyakit kardiovaskular meningkat dikarenakan oleh berbagai faktor, salah satunya adalah kadar homosistein darah yang akan berpengaruh pada risiko terjadinya aterosklerosis yang merupakan dasar dari terjadinya berbagai jenis penyakit kardiovaskular dikarenakan homosistein akan menyebabkan kerusakan dinding endotel pembuluh darah dan diikuti dengan terjadinya aterosklerosis. ${ }^{(16)}$ Teori tersebut didukung juga oleh penelitian dari Bambang Irawan et al menyatakan bahwa risiko penyakit kardiovaskular pada lansia dipengaruhi oleh tekanan dan kadar kolesterol total, dimana hipertensi dan jumlah kolesterol total yang tinggi 
Tabel 2. Hubungan asupan gizi (vitamin B6, B9, dan B12) dengan risiko penyakit kardiovaskular

\begin{tabular}{|c|c|c|c|c|c|}
\hline \multirow[b]{2}{*}{ Variabel } & \multicolumn{4}{|c|}{ Risiko penyakit kardiovaskular } & \multirow[b]{2}{*}{$\mathbf{p}$} \\
\hline & $\begin{array}{c}\text { Rendah } \\
\text { n (\%) }\end{array}$ & $\begin{array}{c}\text { sedang } \\
\text { n (\%) }\end{array}$ & $\begin{array}{l}\text { tinggi } \\
\text { n (\%) }\end{array}$ & Total & \\
\hline \multicolumn{6}{|l|}{ Vitamin B6 } \\
\hline $\begin{array}{l}\text { Kurang } \\
\text { Cukup }\end{array}$ & $\begin{array}{l}2(12.5) \\
53(69.7)\end{array}$ & $\begin{array}{l}11(68.8) \\
22(28.9)\end{array}$ & $\begin{array}{c}3(18.8) \\
1(1.3)\end{array}$ & $\begin{array}{l}16 \\
76\end{array}$ & $0.000 *$ \\
\hline \multicolumn{6}{|l|}{ Vitamin B9 } \\
\hline $\begin{array}{l}\text { Kurang } \\
\text { Cukup }\end{array}$ & $\begin{array}{l}20(42.6) \\
35(77.8)\end{array}$ & $\begin{array}{l}23(48.9) \\
10(22.2)\end{array}$ & $\begin{array}{l}4(8.5) \\
0(0.0)\end{array}$ & $\begin{array}{l}47 \\
45\end{array}$ & $0.001 *$ \\
\hline \multicolumn{6}{|l|}{ Vitamin B12 } \\
\hline $\begin{array}{l}\text { Kurang } \\
\text { Cukup }\end{array}$ & $\begin{array}{l}22(45.8) \\
33(75.0)\end{array}$ & $\begin{array}{l}23(47.9) \\
10(22.7)\end{array}$ & $\begin{array}{l}3(6.3) \\
1(2.3)\end{array}$ & $\begin{array}{l}48 \\
44\end{array}$ & $0.017^{*}$ \\
\hline
\end{tabular}

Keterangan: $\mathrm{n}=$ jumlah sampel, \%=persen, *Uji Fisher, $\mathrm{p}=$ tingkat kemaknaan

akan meningkatkan risiko terjadinya aterosklerosis selain akibat dari peningkatan homosistein, hiperhomosisteinemia menurunkan ketersediaan NO melalui peningkatan inaktivasi oksidatif $\mathrm{NO}$ atau penghambatan produksi $\mathrm{NO}$ oleh asimmetrik dimetilarginin (ADMA) yang akan berpengaruh pada dilatasi mikrovaskular. ${ }^{(17,18)}$ Hasil dari penelitian ini menunjukkan bahwa asupan (vitamin B6, B9, dan B12) yang cukup mempunyai risiko kardiovaskular yang rendah. Hasil yang didapat sesuai dengan hasil penelitian yang menyatakan bahwa peningkatan kadar homosistein total dalam darah berhubungan dengan resiko kardiovaskular pada laki-laki, usia lanjut, merokok, dan tekanan darah tinggi serta peningkatan kadar kolesterol dan kurang berolahraga dan juga kenaikan $>5$ $\mathrm{mmol} / \mathrm{L}$ homosistein mempunyai hubungan signifikan dengan risiko penyakit jantung iskemik, thrombosis vena, emboli paru dan stroke. ${ }^{(19,20)}$ Hasil yang didapat ini yang sejalan dengan teori yang menyatakan bahwa asupan (vitamin B6, B9, dan B12) yang cukup akan mempengaruhi resiko kardiovaskular karena vitamin B akan memaksimalkan metabolisme homosistein melalui 2 jalur reaksi transmetilasi dan jalur transsulfurasi atau jalur remetilasi menjadi sistein yang berperan dalam terjadinya aterosklerosis. ${ }^{(14)}$

Asupan (vitamin B6, B9, dan B12) kategori kurang mempunyai risiko kardiovaskular risiko sedang sebanyak 33 orang (35.9\%) sehingga belum tentu asupan yang kurang akan berdampak pada risiko tinggi penyakit kardiovaskular sebab, ada beberapa faktor lain yang dapat mengakibatkan seseorang mempunyai risiko tinggi seperti kebiasan merokok dan riwayat penyakit diabetes melitus. Masih terdapat perdebatan apakah peningkatan serum homosistein berdampak pada peningkatan risiko penyakit kardiovaskular, sebab ada anggapan bahwa peningkatan homosistein terjadi akibat mutase dalam pengkodean gen untuk enzim methylenetetrahydrofolate reductase (MTHFR) yang berperan dalam metabolisme homosistein. (21,22) Hasil penelitian ini berbeda dengan hasil yang didapatkan oleh The Heart Outcomes Prevention Evaluation (HOPE) yang menyatakan bahwa kombinasi suplemen asam folat, vitamin B6, dan B12 tidak bermakna mengurangi kejadian serangan jantung maupun stroke. Perbedaan hasil ini dapat disebabkan karena rentan umur yang diteliti oleh peneliti tersebut berbeda, penelitian tersebut pada pasien yang telah terdiagnosis memiliki penyakit kardiovaskular kemudian diberikan intervensi untuk pemberian vitamin B6, B9 dan B12 untuk melihat apakah dapat menurunkan risiko penyakit kardiovaskular dan responden penelitian tersebut berasal dari beberapa negara, sehingga sampel sangat bervariasi bila dibandingkan dengan populasi pada penelitian ini. ${ }^{(23)}$ Keterbatasan pada penelitian ini adalah sulitnya para responden untuk mengingat asupan makanan yang dikonsumsi selama satu bulan sehingga butuh waktu yang lebih banyak saat wawancara dan dibutuhkan waktu pengambilan sampel yang lebih panjang alat ukur untuk menentukan tingkat risiko penyakit kardiovaskur yaitu WHO/ISH Risk prediction charts memiliki tingkat spesifikasi yang tidak sebaik jika menggunakan Framingham risk score.

\section{KESIMPULAN}

Asupan mikronutrien terutama vitamin B6 pada lansia dalam kategori cukup, memiliki risiko penyakit kardiovaskular tingkat risiko rendah. Asupan vitamin B6, B9 dan B12 berhubungan 
dengan risiko penyakit kardiovaskular pada lansia.

Untuk penelitian selanjutnya disarankan untuk menggunakan alat ukur yang tingkat ketelitiannya lebih baik untuk mengukur tingkat risiko mengalami penyakit kardiovaskular, memperluas variabel bebas yang juga memiliki dampak pada risiko terjadinya penyakit kardiovaskular serta menggunakan metode yang efisien untuk menilai asupan makanan pada lansia. Bagi para dokter disarankan juga untuk lebih memperhatikan asupan makanan khususnya vitamin B6, B9, dan B12 pada pasien usia lanjut yang memiliki penyakit kardiovaskular.

\section{REFERENSI}

1. Kementrian Kesehatan Republik [KEMENKES] Indonesia. INFODATIN Pusat Data dan Informasi Kementrian Kesehatan RI Lansia Nasional, 2016.

2. Kementrian Kesehatan Republik Indonesia. INFODATIN Pusat Data dan Informasi Kementrian Kesehatan RI Jantung, 2014.

3. Gugun AM. Hiperhomosisteinemia dan faktor risiko kelainan vaskular. Mutiara Medika. 2008;8(2):97-105.

4. Triana V. Macam - macam vitamin dan fungsinya dalam tubuh manusia. Staf Pengajar PSIKM FK Unand. 2016;I(1):40-7.

5. Murray RK, Bender DA, Botham KM, et al. Micronutrient : vitamins and mineral in Harper's Illustrated Biochemistry $28^{\text {th }}$ ed. New York:McGraw-Hill, 2009. p 475-8.

6. Bønaa KH, Njølstaad I, Ueland PM, et al. Homocysteine lowering and cardiovascular events after acute myocardial infarction. N Engl J Med. 2006;(354):1578-88.

7. Marks DB, Markks AD, Smith CM. Synthesis of Fatty Acids, Triacylglycerols, and the Major Membrane Lipids in Biokimia kedokteran dasar. Jakarta: EGC, 2001. p.602-67.

8. Kumar, Abbas, Fausto, et al. Robbins basic pathology. $8^{\text {th }}$ edition. Singapore: Elsevier, 2007. p343-53.

9. Lintong PM. Perkembangan konsep patogenesis aterosklerosis. Patologi Klinik Anatomi FK UNSRAT. 2009 Mar; 1(1):12-22.

10. Chambers JC, Obeid OA, Refsum H, et al. Plasma homocysteine concentrations and risk of coronary heart disease in UK Indian, Asian and European men. Lancet. 2000;355: 523-7.

11. Debreceni B, Debreceni L. Role of vitamins in cardiovascular health and disease. Dove Press Journal : Research reports in clinical cardiology. 2014;5:283-95. DOI https://doi.org/10.2147/ RRCC.S44465

12. Zhang C, Wang ZY, Qin YY, et al. Association between $\mathrm{B}$ vitamins supplementation and risk of cardiovascular outcomes: a cumulative metaanalysis of randomized controlled trials. PLoS One. 2014;9(9):e107060. doi: 10.1371/journal. pone.0107060. eCollection 2014

13. Gouaille CB. Focus on homocysteine and the vitamins $1^{\text {st }}$ ed. Paris: Springer. 2001. p11-9
14. Pusparini. Homosistein faktor risiko baru (non tradisional) penyakit kardiovaskular. Patologi Klinik FK Universitas Trisakti. 2002 Jan-April; 21(1):31-9.

15. Brattstrom L, Wilcken DE. Homoscysteine and cardiovascular disease. American society clinical nutrition. 2000;72: 315-23.

16. Aman AK, Ginting AA, Anwar Y. Kadar homosistein pada penderita stroke iskemik trombotik. Departemen/SMF Patologi Klinik \& Penyakit Saraf FK USU. 2005 Sep; 38(3):219-22.

17. Irawan $B$, Sja'bani M, Astoni MA. Hiperhomosisteinemia sebagai risiko penyakit jantung koroner. Kardiologi dan Vaskular, Ilmu Penyakit Dalam FK Universitas Gadjahmada. 2005 Des; 21(3):103-10.

18. Sunarti, Asdie AH, Asdie, et al. Hubungan Antara Homosistein dan Nitrit Oksid Pada Hipertensi Esensial Di Jawa Tengah. Kedokteran masyarakat. 2007 Juni; 23 (2):58-63.

19. Nygard O, Vollset SE, Refsum H et.al. Total plasma homocysteine and cardiovascular risk profile. JAMA 1995;27:1526-32.

20. Wald DS, Law M, Morris JK. Homocysteine and cardiovascular disease. BMJ 2002;325:1-7.

21. Frosst P, Blom HJ, Milos R, et al. A candidate genetic risk factor for vascular disease: a common mutation in methylenetetrahydrofoloate reductase. Nat Genet 1995; 10:111-3.

22. Brattstrom L, Wilcken DEL, Ohrvik J, et al. Common methylene- tetrahydrofolate reductase gene mutation leads to hyperhomocysteinemia but not to vascular disease. Circulation 1998;98:25206.

23. The Heart Outcomes Prevention Evaluation [HOPE]. Homocysteine lowering with folic acid and $b$ vitamins in vascular disease. NEJM. 2006 April: 354(15):1567-77. 